\title{
KARAKTERISTIK REKAHAN BATUBARA \\ PADA EKSPLORASI GAS METANA BATUBARA DI CEKUNGAN OMBILIN, PROVINSI SUMATERA BARAT
}

\section{CLEAT CHARACTERISTIC ON COALBED METHANE EXPLORATION IN OMBILIN BASIN, WEST SUMATRA PROVINCE}

\author{
Muhammad Abdurachman Ibrahim dan Denni Widhiyatna \\ Pusat Sumber Daya Mineral, Batubara dan Panas Bumi \\ Ibrahim_lubis@yahoo.com
}

\begin{abstract}
ABSTRAK
Eksplorasi Coal Bed Methane atau gas metana batubara telah dilakukan di Sawahlunto, Provinsi Sumatera Barat oleh Pusat Sumber Daya Geologi pada tahun 2009. Daerah ini termasuk dalam Cekungan Ombilin. Pengeboran gas metana batubara mencapai kedalaman 451 meter, menembus Formasi Sawahlunto dengan lingkungan delta. Di daerah ini terdapat 5 lapisan batubara, yaitu A, B, C, D, dan E. Salah satu karakteristik yang dapat diamati adalah rekahan batubara (cleat). Analisis microcleat digunakan untuk melihat kenampakan maseral, mineral lain, bukaan rekahan (aperture), dan spasi rekahan (spacing). Analisis ini juga memberikan gambaran porositas dan permeabilitas, serta kandungan gas, berdasarkan ciri fisik bukaan dan spasi rekahan batubara. Analisis ini memberikan gambaran bahwa semakin dalam batubara, maka akan semakin buruk permeabilitasnya, kandungan gas akan baik bila bukaan lebar, menerus, dan tidak terisi mineral, serta semakin bersih batubara dengan kilap gelas. Hal ini akan memberikan rekahan yang banyak dan memiliki komposisi gas metana yang baik.
\end{abstract}

Kata kunci: gas metana batubara, batubara, rekahan, Cekungan Ombilin

\section{ABSTRACT}

CBM exploration, which was carried out by the Centre for Geological Resources, is located in Sawahlunto, West Sumatra Province. This area is included in the Ombilin Basin. The coal bed methane drilling reached 451 meters, penetrating the Sawahlunto Formation of the deltaic depositional environment. There are five coal seams, namely $A, B, C, D$, and $E$. One of characteristics that can be observed is the coal fracture (cleats). A microcleat analysis is used to view the appearance of maceral, minerals, cleat aperture, and cleat spacing. The analysis also shows the porosity and permeability, as well as gas content, based on physical characteristics of cleat aperture and spacing. The analysis illustrates that deeper coal seam has worse permeability, gas content would be better if cleat wide openings, continuous, and not filled with minerals, as well as clean coal with glassy it would give a lot of fracture and good methane gas composition.

Keywords: coalbed methane, coal, cleat, Ombilin Basin

\section{PENDAHULUAN}

Lokasi penelitian terletak di Kelurahan Air Dingin, Kecamatan Lembah Segar, Kota Sawahlunto, Provinsi Sumatera Barat.
Secara geografis, lokasi ini terletak pada koordinat $0^{\circ} 36^{\prime} 00^{\prime \prime}-0^{\circ} 42^{\prime} 00^{\prime \prime}$ LS dan $100^{\circ} 45^{\prime} 00^{\prime \prime}-100^{\circ} 48^{\prime} 00^{\prime \prime}$ BT. Secara regional, daerah penelitian termasuk dalam Cekungan Ombilin (Gambar 1). 


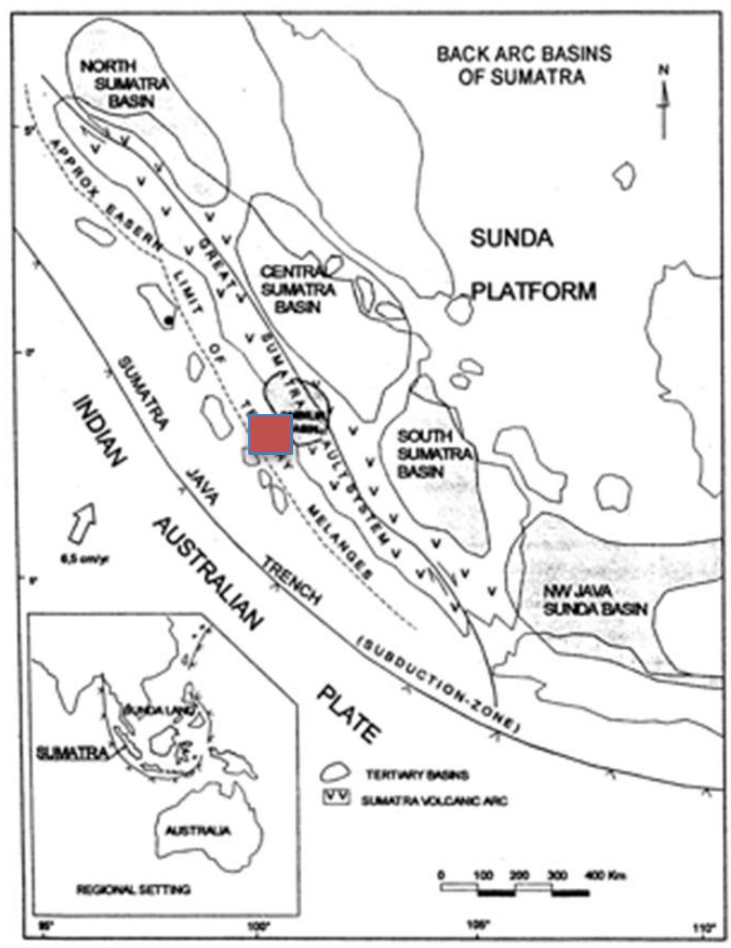

Gambar 1. Lokasi Penelitian

Data hasil analisis batubara di daerah ini diperoleh dari hasil kegiatan pengeboran batubara dalam rangka pengungkapan potensi gas metana batubara yang

\section{TINJAUAN PUSTAKA}

Lapisan batubara dapat menjadi batuan induk dan reservoir, karena itu gas metana batubara diproduksi secara in-situ, tersimpan pada macropore, mesopore, dan micropore (Gambar 2). Gas tersebut tersimpan pada rekahan dan sistem pori pada batubara hingga pada saat air mengubah tekanan pada reservoir. Gas kemudian keluar melalui matriks batubara dan mengalir melalui rekahan sampai pada sumur (Gambar 3). Gas tersebut sering kali terjebak pada rekahan-rekahan (cleat) batubara.

Sistem rekahan pada batubara sangat penting untuk dipelajari, karena permeabilitas ditentukan dari rekahanrekahan batubara ini. Walaupun batubara mempunyai porositas yang besar, tetapi sistem rekahan ini merupakan jalan utama alamiah dari gas dan air yang dapat mempengaruhi ekonomis tidaknya suatu dilakukan oleh Pusat Sumber Daya Geologi, Badan Geologi, pada Oktober hingga November 2009.

program pengembangan eksplorasi gas dalam batubara. Kehadiran rekahan tersebut disebabkan oleh berbagai faktor meliputi mekanisme pengendapan, maseral pembentuk, derajat pembatubaraan, dan kejadian tektonik.

Rekahan-rekahan pada batubara dapat terbentuk bersamaan dengan proses pembatubaraan dan atau pengaruh tektonik. Rekahan yang dipengaruhi oleh tektonik tidak ada bedanya dengan rekahan dari proses pembatubaraan. Rekahan yang terjadi pada saat pembatubaraan terjadi karena memadatnya batubara oleh pengaruh tekanan dan temperatur. Rekahan tersebut umumnya ortogonal dan hampir tegak lurus dengan perlapisan. Orientasi dan kehadiran rekahan batubara dalam lapisan batubara mempengaruhi pemilihan tata letak tambang dan sumur bor, arah pengambilan batubara, serta aplikasi teknologi eksplorasi dan eksploitasi batubara. 


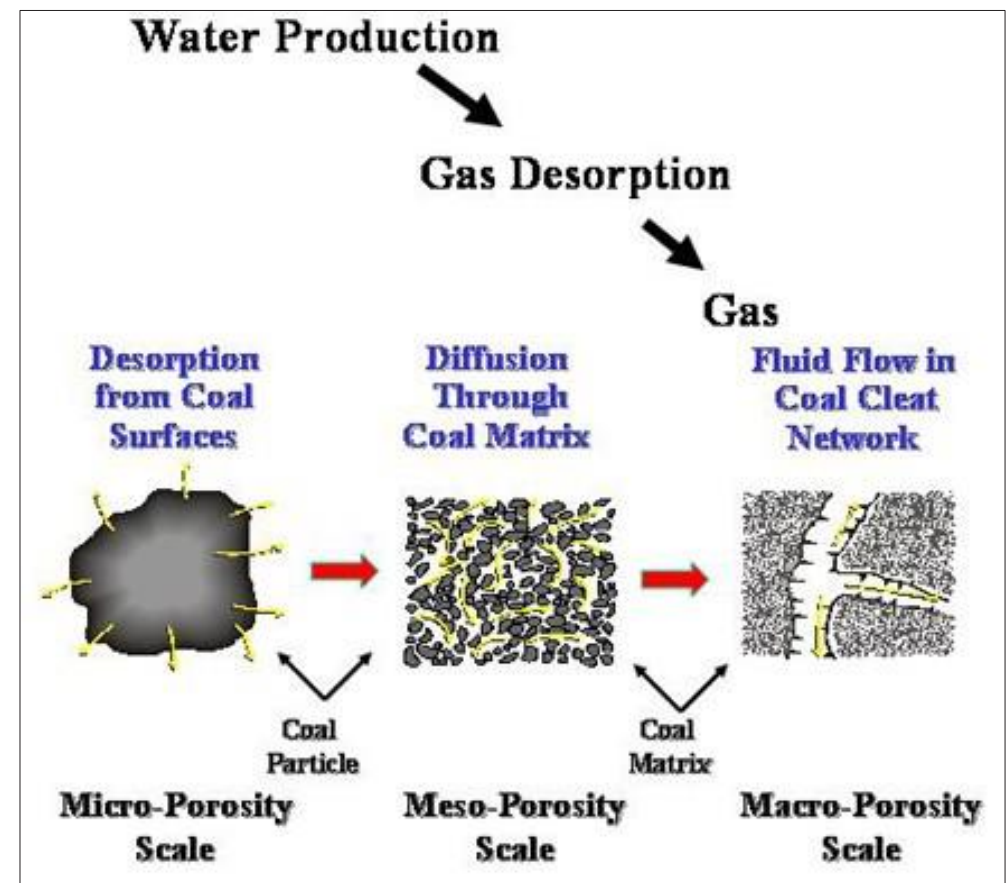

Gambar 2. Kaitan antara porositas mikro, meso, dan makro (http://energy.usgs.gov/factsheets/Forest/fig1.html)

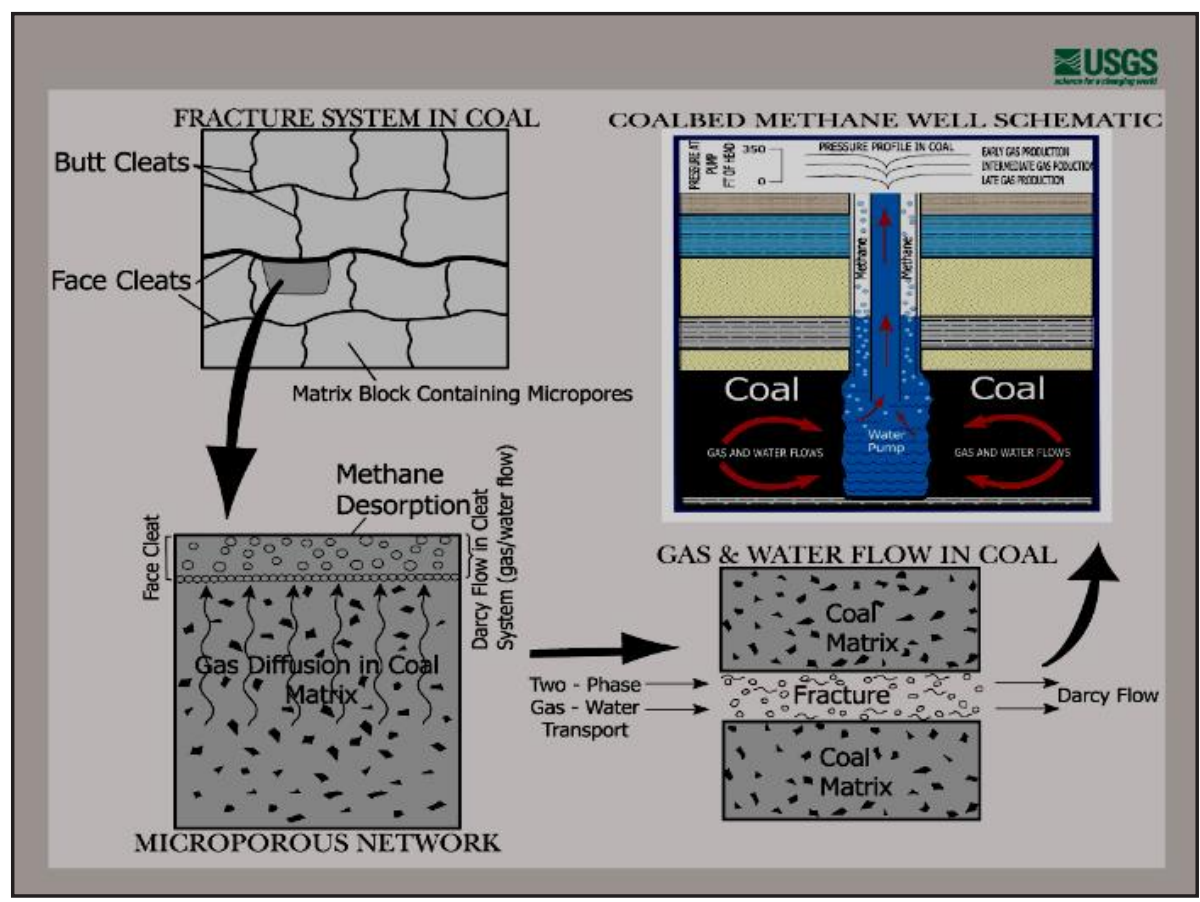

Gambar 3. Gambar skematik gas metana dari matriks menuju sumur (USGS, 2006 dalam Cahyono dan Simatupang, 2007)

Secara geometri rekahan pada batubara dibagi menjadi dua yaitu face cleat, rekahan yang bersifat lebih menerus, sebagai rekahan primer, bidang rekahan ini biasanya tegak lurus dengan bidang perlapisan, serta butt cleat, rekahan yang kurang menerus, kemenerusan dibatasi oleh face cleat, bidang rekahan ini tegak lurus dengan face cleat. Komponen lain dalam rekahan batubara yaitu bukaan (aperture) yang merupakan dimensi celah yang terbuka dalam rekahan tersebut, dan 
spasi (spacing) yang merupakan dimensi jarak antar rekahan (Gambar 4).

Spasi dan bukaan dalam rekahan batubara dipengaruhi oleh peringkat batubara, tebal lapisan, dan maseral. Spasi dan bukaan rekahan batubara berkurang dari peringkat batubara sub-bituminus hingga mediumlow volatile bituminous, kemudian bertambah lagi pada peringkat batubara antrasit. Keadaan ini dikarenakan derajat pembatubaraan yang naik, sehingga akibat tekanan dan temperatur, rekahan-rekahan yang ada cenderung mengecil.

Tebal lapisan batubara mempengaruhi perkembangan rekahan. Lapisan batubara yang tipis membuat rekahan berkembang, sedangkan lapisan batubara yang tebal rekahan kurang berkembang. Lapisan batubara yang mempunyai ciri batubara mengkilap (kilap gelas), biasanya dibentuk oleh maseral yang kaya vitrinit, mempunyai rekahan yang banyak. Batubara yang kurang mengkilap (dull) juga ditemukan rekahan, tetapi kurang berlimpah dibandingkan lapisan batubara yang mengkilap.

Arah gaya tektonik (stress) yang terjadi pada daerah penelitian juga mempengaruhi permeabilitas (Gambar 5). Bila arah gaya tektonik sejajar dengan arah face cleat batubara, maka permeabilitas akan besar. Sebaliknya bila arah gaya tektonik tegak lurus dengan arah face cleat, maka permeabilitas akan kecil. Hal ini disebabkan karena tekanan yang diberikan bukan melewati face cleat, melainkan melalui butt cleat (Olsen dkk., 2003).

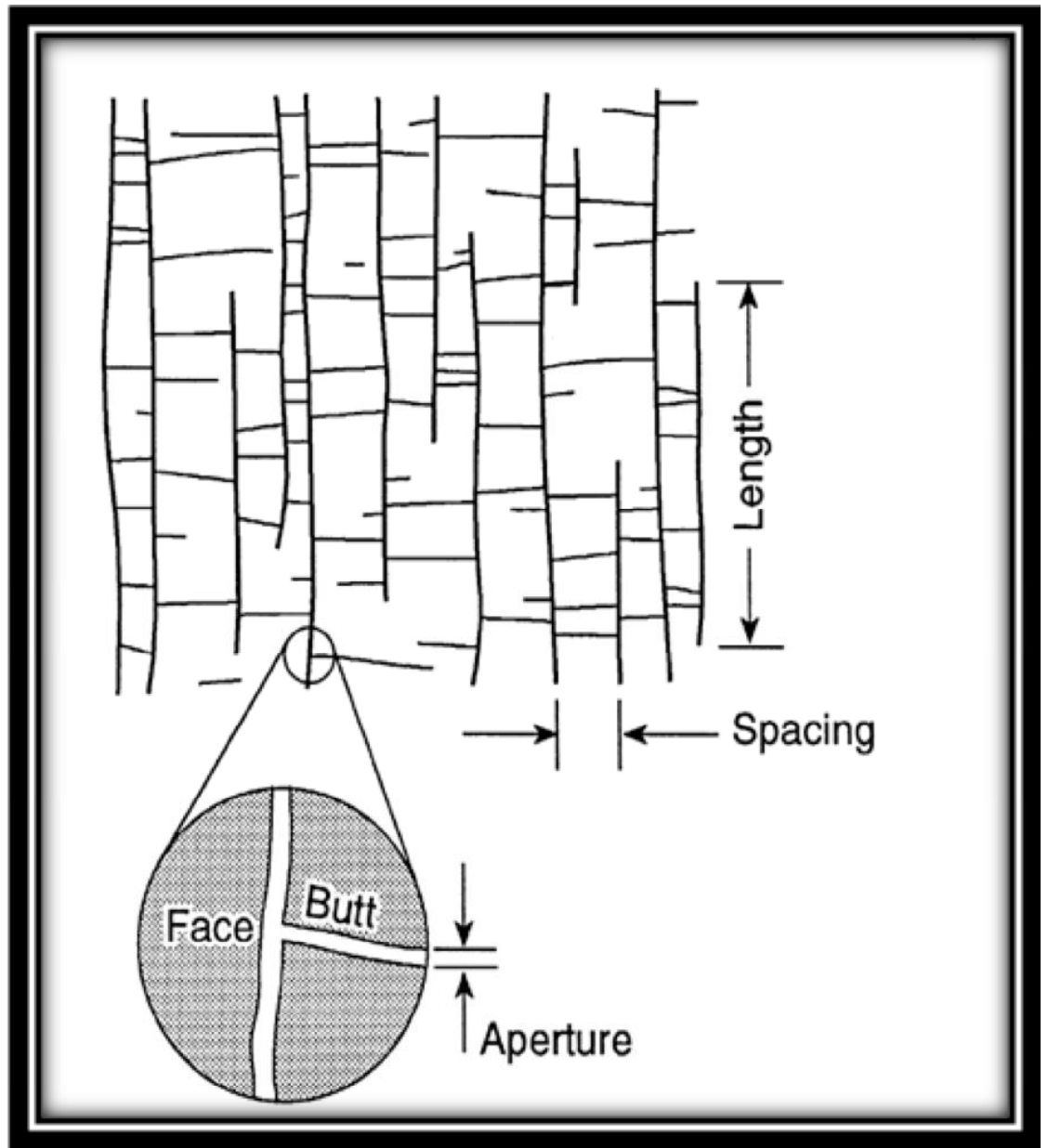

Gambar 4. Komponen dalam rekahan batubara (Indobarambai Gas Methane). 


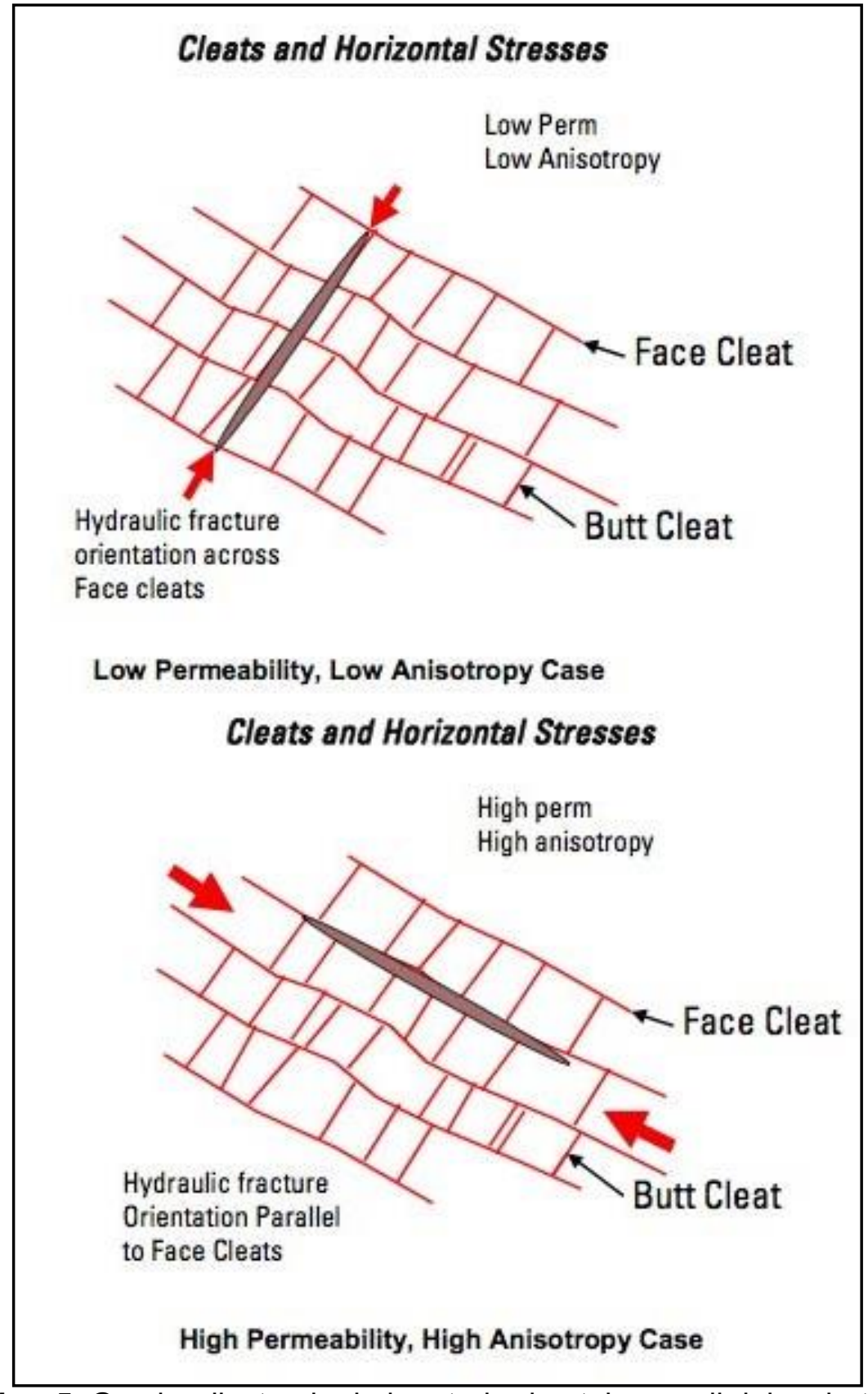

Gambar 5. Gambar ilustrasi rekahan terhadap tekanan di dalam batubara (Olsen dkk., 2003).

\section{GEOLOGI DAERAH PENELITIAN}

Cekungan Ombilin merupakan cekungan antargunung (intermountain basin). Cekungan ini merupakan sebuah graben dengan tektonik ekstensional dan struktur yang kompleks. Jurus perlapisan batuan pada daerah penelitian relatif utara-selatan dan kemiringan batuan relatif ke arah timur dengan sudut antara $15^{\circ}$ s.d. $35^{\circ}$. Daerah penelitian termasuk ke dalam homoklin, karena perlapisan batuan mempunyai arah kemiringan yang relatif sama.

Stratigrafi daerah penelitian terdiri dari Formasi-formasi:

Sawahlunto,

Sawahtambang Anggota Rasau, dan Sawahtambang (Gambar 6). Formasi Sawahlunto Eosen merupakan sedimen Tersier yang paling tua yang tersingkap pada daerah penelitian. Formasi ini merupakan formasi pembawa batubara, 
terdiri dari perulangan serpih dan batulanau dengan sisipan batupasir halus dengan struktur laminasi sejajar, lingkungan pengendapan delta pada batubara (bagian bawah Formasi Sawahlunto) dan sungai kekelokan (meander) pada bagian atas (Noeradi dkk., 2005). Lingkungan pengendapan ini terpengaruh oleh adanya fluktuasi muka air laut. Hal ini diperlihatkan oleh hadirnya pirit berdasarkan analisis petrografi batubara. Lingkungan pengendapan ini diperkuat oleh adanya batuan sedimen klastik halus sebagai pengotor pada saat muka air laut naik.

Formasi Sawahtambang Anggota Rasau berumur Oligosen, terletak selaras di atas Formasi Sawahlunto, terdiri dari perulangan batupasir konglomeratan dan batupasir sangat kasar berwarna coklat kemerah-merahan dengan sisipan batulanau dan batulempung berwarna abuabu sampai ungu, fragmen utama kuarsa, lingkungan pengendapan dataran banjir dengan sungai kekelokan yang rendah lekukannya (Koesoemadinata \& Matasak, 1981).

Formasi Sawahtambang berumur Oligosen, terletak selaras di atas Formasi Sawahtambang Anggota Rasau, terdiri dari batupasir halus sampai sangat kasar bahkan konglomeratik dengan fragmen yang dominan kuarsa. Batulempung, serpih, dan batulanau hanya setempat saja, berwarna abu-abu muda sampai coklat, terlihat struktur sedimen silang siur dan laminasi sejajar dengan sekuen menghalus ke atas, lingkungan pengendapan dataran banjir dengan sungai kekelokan yang rendah lekukannya (Koesoemadinata dan Matasak, 1981).

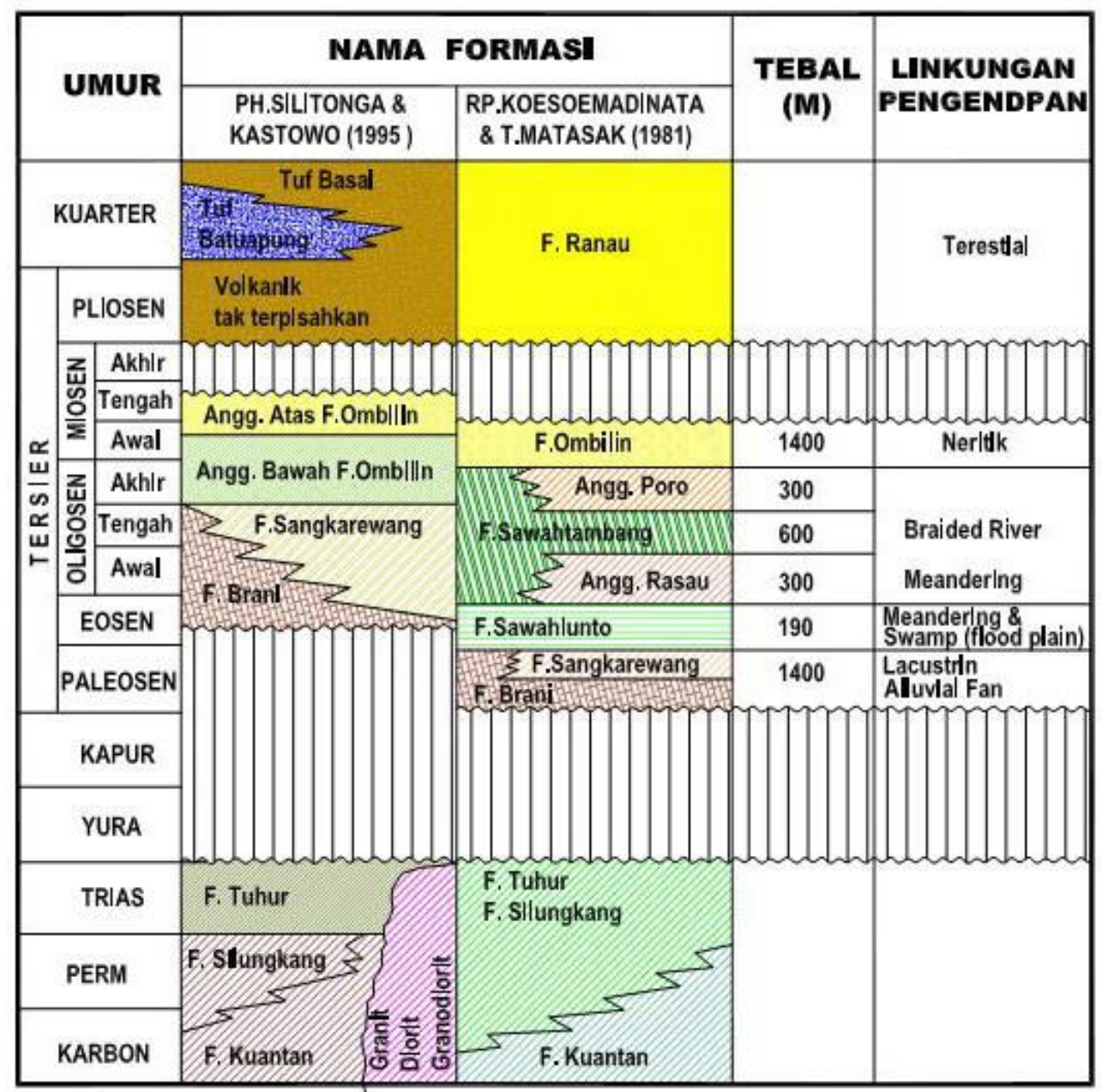

Gambar 6. Stratigrafi Cekungan Ombilin 


\section{METODOLOGI}

Metode yang digunakan dalam penelitian ini adalah dengan melakukan pengeboran batuan inti (full coring) menggunakan mesin bor Long Year 38, secara vertikal, sampai kedalaman 451 meter. Lokasi titik bor diberi notasi AD-01 di wilayah Air Dingin, Sawahlunto.

Pengukuran kandungan gas dengan
metode langsung menggunakan karakteristik pelepasan gas dari batubara (desorption). Batubara yang keluar dari hasil pengeboran, berupa batuan inti (core), dimasukkan ke dalam tabung (kanister) yang tertutup rapat untuk dilakukan pengukuran gasnya. Komposisi gas diuji menggunakan gas chromatography.

Analisis laboratorium berupa analisis petrografi organik, proksimat, nilai kalori batubara, dan adsorption isotherm. Analisis petrografi organik dilakukan untuk melihat material organik (maseral) pembentuk batubara serta reflektansi vitrinit. Analisis proksimat menentukan jumlah air (moisture), zat terbang (volatile matter), abu (ash), karbon tertambat (fixed carbon), berat jenis, dan nilai kalori batubara. Analisis adsorption isoterm merupakan metode penghitungan kandungan gas secara tidak langsung dengan cara menghitung jumlah gas yang dapat diserap oleh batubara dengan tekanan pada temperatur tertentu.

Analisis rekahan batubara dengan mengukur face cleat dan butt cleat pada singkapan batubara. Microcleat dilihat di bawah mikroskop untuk melihat bukaan dan spasi rekahan batubara tersebut. Porositas dan permeabilitas dihitung berdasarkan hasil analisis rekahan batubara.

\section{HASIL DAN PEMBAHASAN}

\section{Lapisan Batubara}

Formasi pembawa batubara di daerah penelitian adalah Formasi Sawahlunto bagian bawah berumur Eosen. Berdasarkan hasil pengeboran didapatkan lapisan batubara A, B, C, D, dan E. Lapisan batubara A secara megaskopis berwarna hitam, mengilap (bright), terdapat rekahan batubara, dan ada lapisan pengotor antara $2 \mathrm{~cm}$ s.d. $5 \mathrm{~cm}$. Di bagian atas dan di bawah lapisan batubara terdapat batulempung dan batulempung karbonan.

Lapisan batubara B secara megaskopis relatif sama dengan lapisan batubara $A$. Di atas dan di bawah lapisan batubara B terdapat batulempung dan sedikit batulempung karbonan.

Lapisan batubara C merupakan lapisan yang paling tebal dengan kualitas yang lebih baik dari batubara di atasnya. Di dalam lapisan batubara $C$ terdapat tiga lapisan pengotor yang tebalnya mencapi 5 $\mathrm{cm}$. Di atas dan di bawah lapisan batubara C terdapat batulempung dan sedikit batulempung karbonan.

Batubara di Sawahlunto memiliki kandungan vitrinit yang dominan antara $80 \%$ s.d. $99 \%$, liptinit antara $1 \%$ s.d. $9 \%$, dan inertinit sangat sedikit, maksimum hingga $6 \%$. Sklerotinit sangat dominan pada kelompok maseral inertinit. Nilai reflektansi vitrinit antara 0,66\% s.d. 0,80\%. Nilai tersebut dalam plot peringkat batubara termasuk ke dalam bituminus zat terbang tinggi. Nilai kalori batubara antara $7.434 \mathrm{kal} / \mathrm{gr} \mathrm{s}$.d. $7.646 \mathrm{kal} / \mathrm{gr}(\mathrm{adb})$.

Litologi berdasarkan pengeboran pada kedalaman 0 meter s.d. 332,10 meter merupakan Formasi Sawahtambang Anggota Rasau dicirikan oleh batupasir berbutir halus sampai kasar, bahkan konglomeratan, dengan fragmen kuarsa, berwarna coklat kemerahan sampai keunguan, sisipan batulanau dan batulempung berwarna abu-abu kemerahan sampai keunguan, sedangkan kedalaman 332,10 meter s.d. 451,00 meter merupakan Formasi Sawahlunto dicirikan oleh batulempung berwarna abu-abu tua kecoklatan sisipan batupasir halus dan batubara. 
Sklerotinit dan pirit hadir cukup banyak pada percontoh kedalaman 382 meter s.d. 383 meter dan kedalaman 392 meter s.d. 393 meter. Keberadaan sklerotinit sebagai penanda bahwa lapisan batubara berada di dekat permukaan, sedangkan pirit sebagai penanda fluktuasi muka air laut. Kedalaman batubara 382 meter s.d. 383 meter diendapkan saat muka air laut turun dan dekat permukaan, kemudian pengaruh air laut hilang dan pengendapan batubara terus menebal, hingga pada saat air laut kembali naik dan batubara kembali dekat ke permukaan pada kedalaman 392 meter s.d. 393 meter. Kondisi seperti ini diinterpretasikan sebagai pengendapan batubara pada lingkungan delta.

\section{Kandungan dan Komposisi Gas}

Persentase kandungan $\mathrm{CH}_{4}$ mendominasi gas yang lainnya. Kandungan $\mathrm{CH}_{4}$ pada lapisan batubara B antara $82,65 \%$ s.d. $85,88 \%$, dengan rata-rata $84,26 \%$ atau 181,97 scf/ton; lapisan batubara C antara
$51,11 \%$ s.d. $70,49 \%$ rata-rata $61,38 \%$ atau 218,50 scf/ton; lapisan batubara $D$ sebesar $61,16 \%$ atau 116,27 scf/ton, dan lapisan batubara $E$ sebesar $57,97 \%$ atau 89,16 scf/ton (Tabel 2).

Hasil pengujian adsorption isotherm menunjukkan bahwa kapasitas simpan (storage capacity) gas metana pada lapisan batubara B kedalaman 370 meter dengan tekanan hidrostatik $3.755 \mathrm{kPA}$ sebesar 7,26 $\mathrm{m}^{3} /$ ton (as received), sedangkan untuk lapisan batubara $\mathrm{C}$ kedalaman 393 meter dengan tekanan hidrostatik $3.979 \mathrm{kPa}$ sebesar $13,73 \mathrm{~m}^{3} /$ ton (as received) (Tabel 3 dan Gambar 7)). Hasil pengukuran langsung kandungan gas metana pada lapisan batubara B baru mencapai $181,97 \mathrm{scf} /$ ton atau $5,16 \mathrm{~m}^{3} /$ ton, dan pada lapisan batubara $\mathrm{C}$ baru mencapai $218,50 \mathrm{scf} /$ ton atau $6,18 \mathrm{~m}^{3} / \mathrm{ton}$. Berdasarkan hasil adsorption isotherm dibandingkan dengan hasil desorption, maka kandungan gas metana pada daerah penelitian masih dapat meningkat lagi.

Tabel 1. Batubara hasil pengeboran di lokasi AD-01

\begin{tabular}{ccccc}
\hline \multirow{2}{*}{ Lapisan } & \multicolumn{2}{c}{ Kedalaman Batubara $(\mathrm{m})$} & \multirow{2}{*}{$\begin{array}{c}\text { Tebal } \\
(\mathrm{m})\end{array}$} & \multirow{2}{*}{ Keterangan } \\
\cline { 2 - 3 } & Dari & Sampai & & \\
\cline { 2 - 3 } & 348,42 & 348,50 & 0,08 & Batubara mengilap \\
\cline { 2 - 4 } A & 348,50 & 351,35 & 2,85 & Lempung batubaraan \\
\cline { 2 - 5 } & 351,35 & 351,55 & 0,20 & Batubara mengilap \\
\cline { 2 - 5 } & 351,55 & 352,05 & 0,50 & Lempung batubaraan \\
\cline { 2 - 5 } & 352,05 & 352,15 & 0,10 & Batubara mengilap \\
\hline B & 369,75 & 371,50 & 1,75 & Batubara mengilap \\
\hline C & 380,24 & 393,80 & 13,56 & Batubara mengilap \\
\hline D & 398,20 & 399,70 & 1,50 & Batubara mengilap \\
\hline E & 401,30 & 402,20 & 0,90 & Batubara mengilap \\
\hline
\end{tabular}

Tabel 2. Hasil kandungan dan komposisi gas di lokasi AD-01

\begin{tabular}{|c|c|c|c|c|}
\hline $\begin{array}{c}\text { Lapisan } \\
\text { Batubara }\end{array}$ & $\begin{array}{c}\text { Gas Content } \\
(\mathrm{scf} / \mathrm{ton})\end{array}$ & $\begin{array}{c}\text { Gas Content } \\
\left(\mathrm{m}^{3} / \text { ton }\right)\end{array}$ & $\begin{array}{c}\text { Methane } \\
\text { Fraction (\%) }\end{array}$ & $\begin{array}{c}\text { Methane Content } \\
(\mathrm{scf} / \text { ton })\end{array}$ \\
\hline $\mathrm{B}$ & 216,32 & 6,13 & 84,26 & 181,97 \\
\hline $\mathrm{C}$ & 355,97 & 10,08 & 61,38 & 218,50 \\
\hline $\mathrm{D}$ & 190,12 & 5,38 & 61,16 & 116,27 \\
\hline $\mathrm{E}$ & 153,82 & 4,36 & 57,97 & 89,16 \\
\hline
\end{tabular}

Tabel 3. Hasil adsorption isotherm

\begin{tabular}{ccccccc}
\hline \multirow{2}{*}{$\begin{array}{c}\text { Kode } \\
\text { percontoh }\end{array}$} & \multicolumn{2}{c}{ Volume dan Tekanan Langmuir } & \multicolumn{2}{c}{ Kapasitas Simpan (m³/ton) } \\
\cline { 2 - 7 } & $\begin{array}{c}\mathrm{V}_{\mathrm{L}} \\
\left(\mathrm{m}^{3} / \mathrm{ton}\right)\end{array}$ & $\begin{array}{c}\mathrm{V}_{\mathrm{L}} \\
(\mathrm{scf} / \mathrm{ton})\end{array}$ & $\begin{array}{c}\mathrm{P} \mathrm{L} \\
(\mathrm{kPa})\end{array}$ & $\begin{array}{c}\mathrm{P} \mathrm{L} \\
(\mathrm{PSI})\end{array}$ & as received & daf \\
\hline AD-1/B & 21 & 742 & 6932 & 1005 & 7,26 & 13,75 \\
\hline AD-1/C & 61 & 2154 & 13702 & 1987 & 13,73 & 15,89 \\
\hline
\end{tabular}



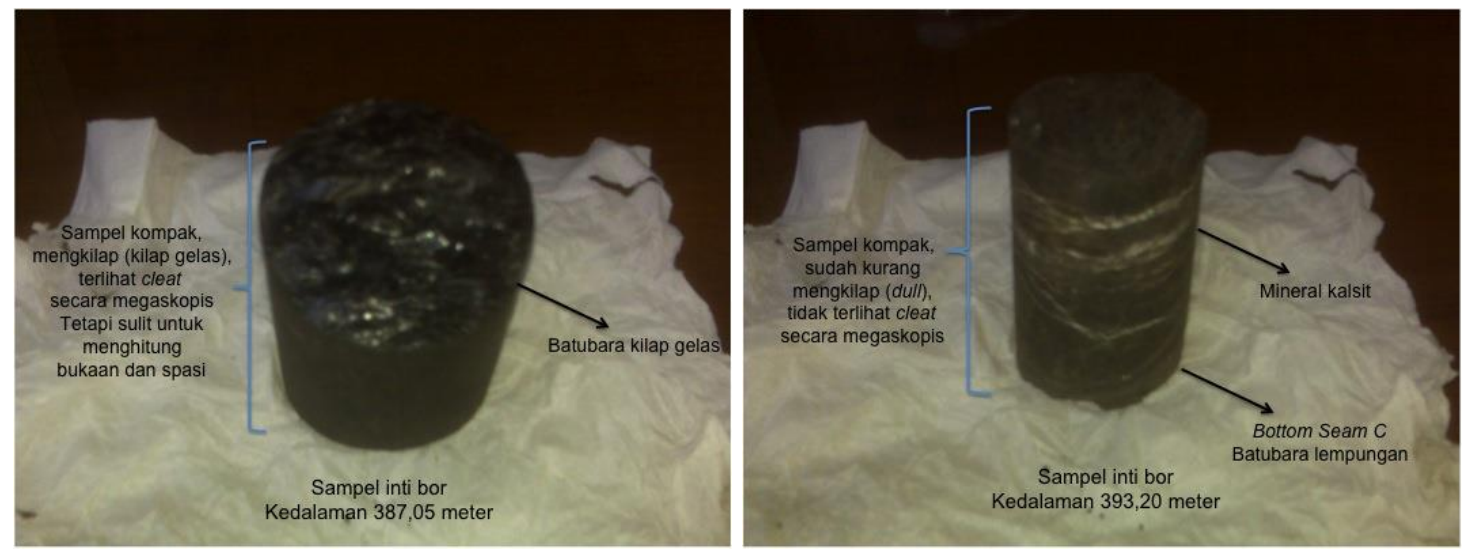

Gambar 7. Percontoh inti bor kedalaman 387,05 meter dan 393,20 meter yang akan dianalisis

\section{Rekahan Batubara}

Permeabilitas dalam batubara bergantung kepada rekahan batubara. Microcleat yang telah diidentifikasi dihubungkan dengan porositas dan permeabilitas batubara. Percontoh batuan yang dianalisis microcleat terdiri dari sepuluh percontoh, satu percontoh dari lapisan batubara B, dan sembilan percontoh dari lapisan batubara C (Tabel 4).

Microcleat yang diamati di bawah mikroskop dihitung spasi (spacing), bukaan (aperture), dan diamati juga kandungan mineralnya. Spasi dan bukaan dihitung sebanyak-banyaknya, kemudian dirataratakan untuk dilakukan perhitungan dengan rumus. Untuk menghitung porositas dan permeabilitas berdasarkan pengamatan spasi dan bukaan dari Ruiz dan Crelling dalam buku applied coal petrology tahun 2008.

Ruiz dan Crelling (2008) mengadopsi Harpalani dan Chen (1995) dalam menentukan porositas dan permeabilitas dari spasi dan bukaan rekahan batubara. Rumusnya adalah sebagai berikut:

$$
\begin{aligned}
& \text { Porositas } \Phi=100.2 \mathrm{a} / \mathrm{s} \\
& \text { Permeabilitas } \mathrm{k}=\mathrm{a}^{3} / 12 \mathrm{~s} \\
& \text { Keterangan: } a=\text { bukaan } \\
& \mathrm{s}=\text { spasi }
\end{aligned}
$$

Analisis microcleat kedalaman 370,50 meter bagian dari lapisan batubara $B$, memperlihatkan rekahan yang banyak, sebagian terisi mineral, bukaan sangat lebar di beberapa tempat, tetapi rekahan cenderung setempat-setempat, sehingga kemenerusan rekahan buruk (Gambar.8).

Perbedaan yang cukup terlihat pada analisis microcleat kedalaman 380,24 meter merupakan bagian atas (top) dari lapisan batubara $\mathrm{C}$, memperlihatkan rekahan yang banyak, bukaan tidak terlalu lebar, bukaan yang lebar cenderung diisi mineral, mulai terlihat mineral pirit, rekahan menerus. Hasil perhitungan porositas maupun permeabilitas menurun dari lapisan batubara B seiring bertambahnya kedalaman (Gambar 8).

Analisis microcleat kedalaman 382,89 meter memperlihatkan rekahan yang tidak terlalu banyak tetapi bukaan lebar, terlihat face cleat dan butt cleat dengan baik, mineral pirit cukup banyak, rekahan menerus tetapi di sisi-sisi rekahan terdapat mineral.

Analisis microcleat kedalaman 383,05 meter masih serupa dengan kedalaman 382,89 meter dikarenakan jarak antar keduanya sangat dekat. Microcleat memperlihatkan rekahan yang tidak banyak tetapi bukaan lebar, rekahan dengan bukaan sempit cenderung tidak menerus, pirit dan sklerotinit sangat jelas terlihat berkumpul membentuk suatu sebaran. 
Tabel 4. Percontoh analisis microcleat dan hasil perhitungan porositas permeabilitas.

\begin{tabular}{cccc}
\hline $\begin{array}{c}\text { Kedalaman } \\
(\text { meter })\end{array}$ & $\begin{array}{c}\text { Lapisan } \\
\text { Batubara }\end{array}$ & $\begin{array}{c}\text { Porositas } \\
(\%)\end{array}$ & $\begin{array}{c}\text { Permeabilitas } \\
(\mathrm{mD})\end{array}$ \\
\hline 370,50 & $\mathrm{~B}$ & 6,95 & 28,28 \\
\hline 380,24 & $\mathrm{C}$ & 5,81 & 16,55 \\
\hline 382,89 & $\mathrm{C}$ & 5,94 & 17,73 \\
\hline 383,05 & $\mathrm{C}$ & 6,08 & 18,96 \\
\hline 384,25 & $\mathrm{C}$ & 5,46 & 13,73 \\
\hline 386,05 & $\mathrm{C}$ & 5,34 & 12,87 \\
\hline 387,05 & $\mathrm{C}$ & 5,29 & 12,51 \\
\hline 392,50 & $\mathrm{C}$ & 4,43 & 7,35 \\
\hline 393,00 & $\mathrm{C}$ & 3,54 & 3,74 \\
\hline 393,20 & $\mathrm{C}$ & 3,46 & 3,48
\end{tabular}
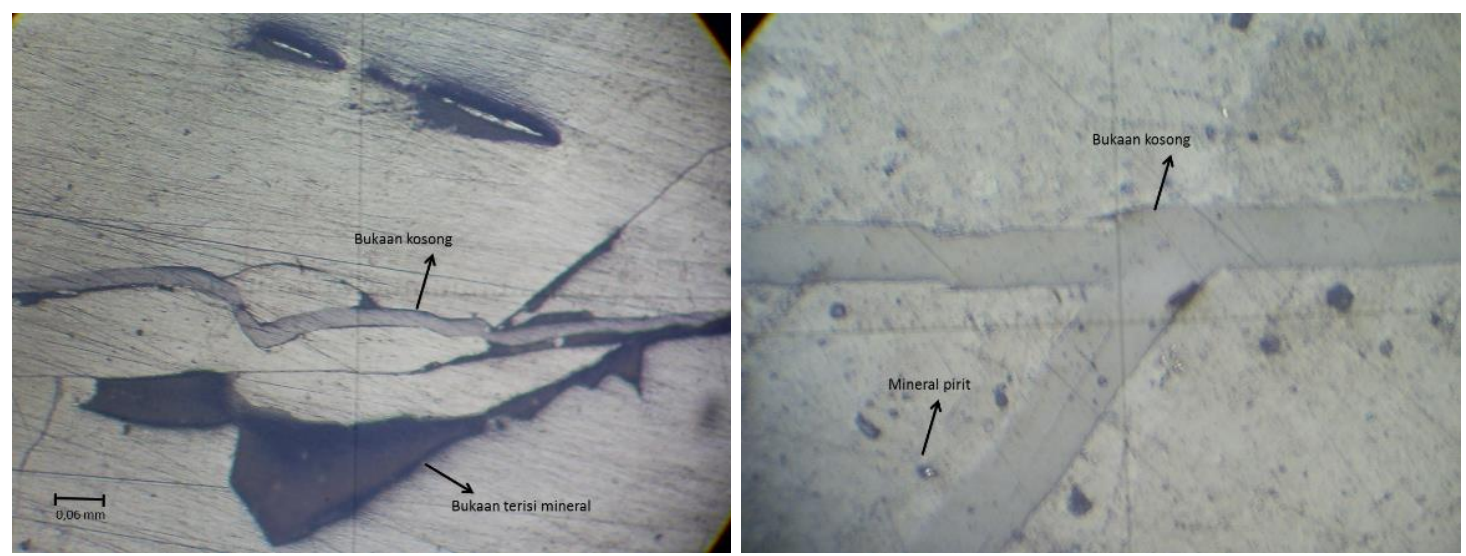

Gambar 8. Kenampakan microcleat pada sampel inti batubara di kedalaman 370,50 meter (kiri) dan 380,24 meter (kanan).

Nilai permeabilitas dan porositas semakin mengecil pada kedalaman 384,25 meter. Analisis microcleat pada memperlihatkan rekahan yang banyak, bukaan sempit, bukaan yang lebar cenderung diisi mineral, spasi rekahan tidak terlalu jauh, mineral pirit mulai tidak ditemukan, rekahan menerus.

Analisis microcleat kedalaman 386,05 meter dapat terlihat dengan baik face cleat dan butt cleat. Microcleat memperlihatkan rekahan yang banyak, bukaan sempit, rekahan banyak yang terisi mineral, face cleat dan butt cleat terkadang bersatu, beberapa rekahan besar bercabang menjadi dua rekahan yang kecil, kemenerusan rekahan kurang baik.

Masih serupa dengan kedalaman 386,05 meter, analisis microcleat pada kedalaman
387,05 meter memperlihatkan rekahan yang bervariasi, terdapat rekahan yang lebar setempat-setempat dan terisi mineral, rekahan yang sempit terkadang kemenerusannya terputus oleh adanya butt cleat yang bersatu dengan face cleat.

Pengamatan pada kedalaman 392,50 meter merupakan pengamatan pada bagian bawah lapisan batubara $\mathrm{C}$. Analisis microcleat pada kedalaman ini memperlihatkan rekahan yang sedikit, rekahan yang lebar sangat sedikit dan terisi mineral, rekahan yang sempit bentuknya tidak lurus menerus tetapi cenderung patah-patah dan hancur, mineral pirit dan maseral sklerotinit mulai terlihat jelas kembali. Penurunan hasil perhitungan nilai porositas dan permeabilitas mulai terlihat. Hal ini disebabkan rekahan batubara yang 
mulai sempit seiring bertambahnya kedalaman lapisan batubara.

Pada percontoh batuan inti kedalaman 393,00 meter dan 393,20 meter terlihat batubara yang sudah kurang mengilap (dull) dan terisi mineral. Analisis microcleat pada kedalaman 393,00 meter memiliki rekahan yang sedikit, rekahan yang lebar maupun sempit sama-sama terisi mineral, rekahan dengan bukaan yang sempit lebih mendominasi, kemenerusan rekahan buruk karena rekahan hancur. Nilai porositas dan permeabilitas yang didapatkan dari hasil perhitungan sangat jauh berbeda dari kedalaman sebelumnya.

Analisis microcleat pada kedalaman 393,20 meter masih serupa dengan kedalaman 393,00 meter. Microcleat terlihat sedikit, bukaan rekahan sempit, tidak menerus dan terisi mineral, mineral pirit masih jelas terlihat, kenampakan petrografi keruh diinterpretasikan banyak mineral lempung mulai masuk. karena percontoh ini merupakan dasar lapisan batubara $\mathrm{C}$.

Analisis microcleat memberikan gambaran bahwa bukaan sempit, tidak menerus, terisi mineral, spasi yang jauh, dan rekahan yang sedikit, akan memberikan nilai permeabilitas yang buruk. Sebaliknya, bukaan yang lebar, menerus, tidak terisi mineral, spasi yang dekat, dan rekahan yang banyak, akan memberikan nilai permeabilitas yang baik.
Porositas yang besar dipengaruhi oleh adanya rekahan yang lebar serta dari matriks batubara itu sendiri. Gas metana akan difusi dari matriks menuju rekahan batubara. Rekahan batubara tetap merupakan porositas yang utama dalam batubara, sehingga semakin lebar bukaan rekahan batubara, maka akan semakin baik porositas batubara. Semakin dalam batubara, maka akan semakin buruk porositas dan permeabilitas. Ciri-ciri fisik memburuknya permeabilitas yang dapat terlihat dengan baik adalah menurunnya jumlah rekahan, bukaan rekahan yang semakin sempit, dan rekahan yang semakin tidak menerus. Adanya mineral yang mengisi rekahan juga menjadi hambatan bagi gas untuk mengalir (Gambar 9 dan Gambar 10).

Batubara yang secara megaskopis terlihat mengilap (kilap gelas) akan cenderung memberikan microcleat yang lebih baik dibandingkan dengan batubara yang kurang mengilap. Batubara pada bagian atas atau bawah dari suatu lapisan batubara akan cenderung banyak pengotor. Pengotor akan mengurangi porositas dan permeabilitas suatu lapisan batubara karena rekahan batubara akan cenderung tertutup oleh pengotor tersebut. Dengan analisis microcleat ini, selain dapat mengidentifikasi maseral, melihat mineral lain, juga dapat mengetahui lingkungan pengendapan, porositas, dan permeabilitas secara lebih komprehensif.

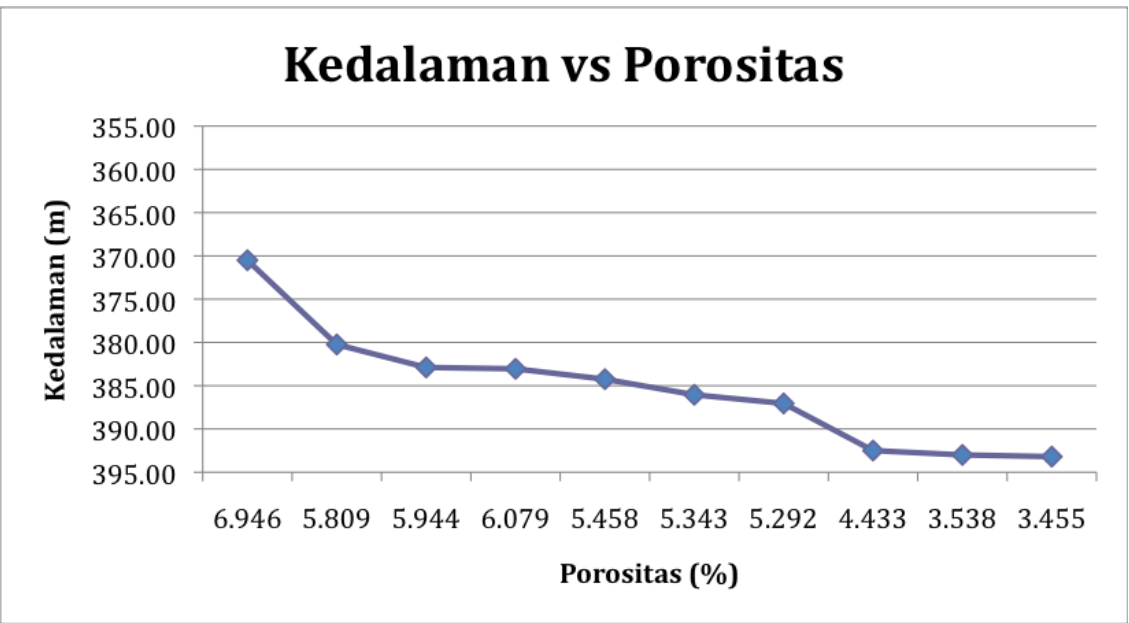

Gambar 9. Plot kedalaman terhadap porositas 
Kandungan gas akan baik bila bukaan lebar, menerus, dan tidak terisi mineral. Kandungan gas juga baik bila bukaan sempit tetapi jumlah rekahan banyak dan spasi rekahan dekat. Beberapa sampel memperlihatkan bukaan yang bervariasi, baik dari bukaan yang lebar, sampai bukaan yang sempit. Variasi ini bila dominan bukaan lebar walaupun kadang terisi mineral, tetap akan memberikan kandungan gas yang besar. Bukaan lebar tetapi hanya setempat-setempat dan tidak menerus akan cenderung memiliki kandungan gas yang buruk (Gambar 11).

Kebersihan percontoh batubara juga mempengaruhi kandungan dan komposisi gas. Percontoh batubara murni dengan kilap gelas, akan memberikan rekahan yang banyak dan menyumbang komposisi gas metana yang banyak pula. Sebaliknya, batubara lempungan akan memberikan rekahan yang buruk, sempit, kecil, dan tidak menerus. Komposisi gas metana pada batubara lempungan juga tidak akan sebaik batubara murni. Batubara kilap gelas disusun oleh kelompok maseral yang kaya vitrinit, sehingga akan memberikan kandungan dan komposisi gas metana yang baik. Kelompok maseral inertinit yang diperlihatkan oleh sklerotinit, akan cenderung mengurangi kandungan dan komposisi gas metana, karena kelompok maseral ini lebih sulit untuk proses hidrogenisasi. Faktor lain yang memengaruhi komposisi gas adalah kandungan unsur mineral, sebagai mineral pengotor, yang dapat mengurangi komposisi gas metana dalam batubara. Mineral pirit sebagai sulfur sekunder diinterpretasikan memberikan peranan dalam mengurangi komposisi gas metana dalam batubara.

Arah utama bidang rekahan utama (face cleat) adalah baratlaut -tenggara dan utaraselatan. Arah face cleat akan paralel dan berhubungan dengan arah kumpulan rekahan regional, sedangkan arah butt cleat tidak akan berhubungan dengan arah kumpulan rekahan regional.

Agar dapat menghasilkan gas metana batubara yang optimal, titik bor selanjutnya diinterpretasikan tidak searah dengan arah utama dari kumpulan face cleat tersebut, melainkan tegak lurus arah utama dari kumpulan face cleat tersebut, yaitu berarah timurlaut-baratdaya dan barat-timur. Hal yang sama juga digunakan untuk bor horizontal, agar dapat menembus beberapa rekahan batubara utama, gunakan arah yang tegak lurus dari kumpulan face cleat tersebut. Dengan demikian, bor horizontal akan efektif menembus beberapa rekahan utama, sehingga diharapkan gas metana batubara yang keluar terdiri dari beberapa reservoir rekahan batubara.

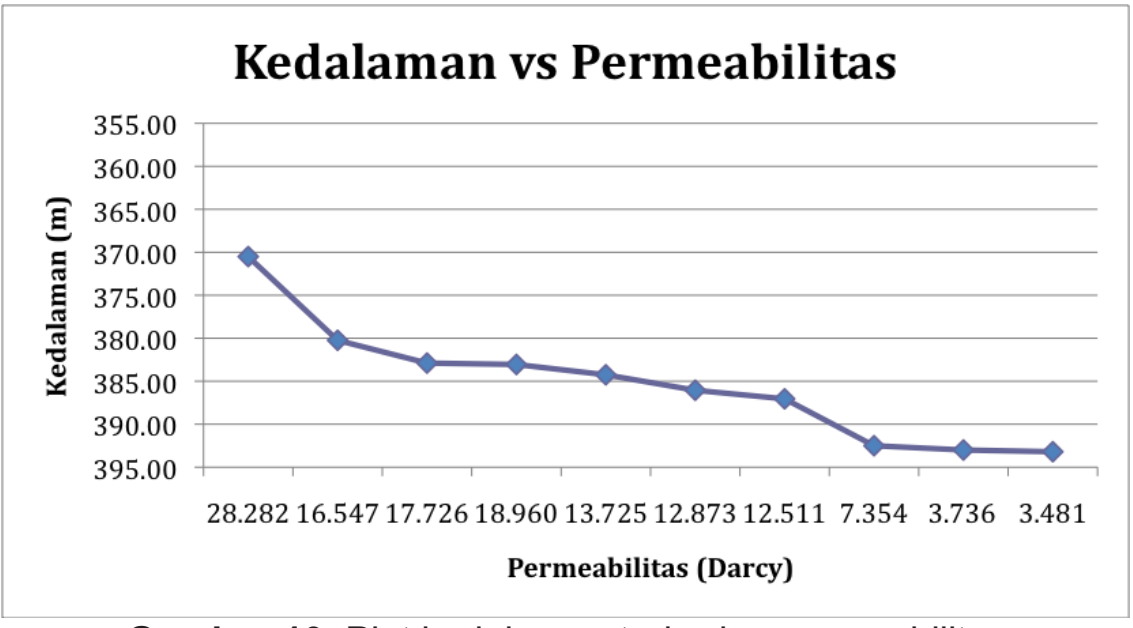

Gambar 10. Plot kedalaman terhadap permeabilitas 


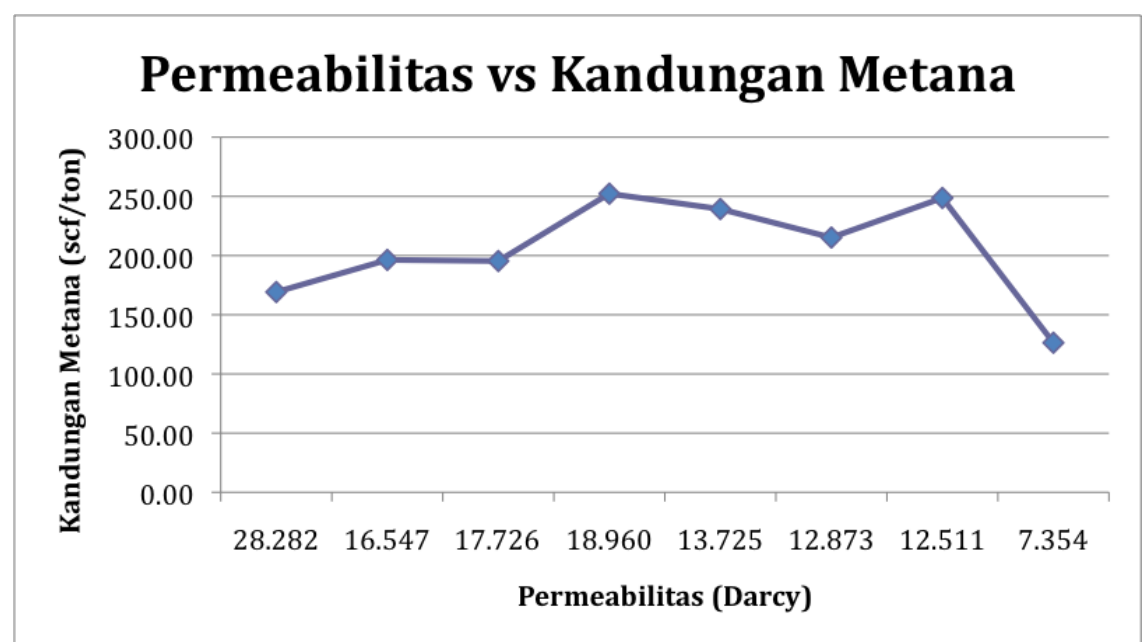

Gambar 11. Plot permeabilitas terhadap kandungan metana.

Arah gaya utama yang membentuk face cleat pada daerah penelitian berarah timurlaut -baratdaya, sama dengan arah gaya tektonik yang terjadi pada saat ini. Arah gaya utama tektonik saat ini tidak sejajar dengan arah utama kumpulan face cleat, sehingga permeabilitas akan cenderung terhambat. Fluida yang melalui face cleat tidak akan terbantu terdorong keluar oleh gaya utama tektonik saat ini, tetapi fluida dalam butt cleat akan terbantu terdorong untuk keluar melalui face cleat.

\section{KESIMPULAN}

Dari pembahasan di atas maka dapat disimpulkan sebagai berikut:

- Analisis microcleat memberikan gambaran bahwa semakin dalam batubara, maka akan semakin buruk permeabilitasnya. Ciri-ciri fisik memburuknya permeabilitas antara lain menurunnya jumlah rekahan, bukaan rekahan yang semakin sempit, dan rekahan yang semakin tidak menerus. Adanya mineral yang mengisi rekahan juga menjadi hambatan bagi gas untuk mengalir

- Analisis microcleat menunjukkan bahwa kandungan gas akan lebih optimal bila bukaan lebar, menerus, dan tidak terisi mineral. Kandungan gas juga lebih optimal bila bukaan sempit tetapi jumlah rekahan banyak dan spasi rekahan dekat. Rekahan dengan dominasi bukaan lebar walaupun terisi mineral, tetap akan memberikan kandungan gas yang besar. Bukaan besar tetapi hanya setempat-setempat dan tidak menerus akan cenderung memiliki kandungan gas yang buruk

- Percontoh batubara murni dengan kilap gelas, akan memberikan rekahan yang banyak dan menyumbang komposisi gas metana yang banyak. Sebaliknya, batubara lempungan akan memberikan rekahan yang buruk, sempit, kecil, dan tidak menerus.

- Kandungan unsur mineral, sebagai mineral pengotor, dapat mengurangi komposisi gas metana. Mineral pirit sebagai sulfur sekunder memberikan peranan dalam mengurangi komposisi gas metana. Kehadiran sklerotinit yang merupakan kelompok maseral inertinit yang sulit untuk proses hidrogenisasi, juga dapat berperan dalam mengurangi komposisi gas metana

- Untuk mendapat gas metana yang optimal, disarankan titik bor selanjutnya tidak searah arah utama face cleat, melainkan tegak lurus arah utama face cleat

\section{UCAPAN TERIMA KASIH}

Ucapan terima kasih ditujukan kepada Kepala Pusat Sumber Daya Mineral Batubara dan Panas Bumi, Kepala Bidang Batubara dan Ir. Deddy Amarullah yang telah memberikan kesempatan kepada penulis untuk memperoleh data. Penulis 
juga mengucapkan terimakasih Prof. Dr. Ir. Eddy Ariyono Subroto, Ir. Benyamin Sapiie, Ph.D., Dr. Ir. Hadiyanto, M.Sc., serta rekanrekan kerja di Bidang Batubara dan Laboratorium PSDMBP yang telah membantu dalam kegiatan penelitian ini.

\section{DAFTAR PUSTAKA}

Brahmantyo, B. dan Bandono, 2006, Klasifikasi Bentuk Muka Bumi (Landform) untuk Pemetaan Geomorfologi pada Skala 1:25.000 dan Aplikasinya untuk Penataan Ruang, Jurnal Geoaplika, Vol.1 No.2, 71-78.

Cahyono, E.B., dan Simatupang, D.P., 2007, Laporan Training Coalbed Methane United States Geological Survey, Denver, Colorado, Pusat Sumber Daya Geologi, Bandung.

Daulay, B., 2001. Pengenalan Batubara, Diklat Teknisi Eksplorasi Batubara, Pusat Pendidikan dan Pelatihan Geologi. Bandung.

Faiz, M., 2008, CBM Workshop: Coal Geology and CBM, CSIRO Australia.

Fletcher, G. dan Yarmanto, 1993, Ombilin Basin Field Guide Book, Indonesian Petroleum Association, Jakarta.

Flores, R.M., 2004, Coalbed Methane in The Powder River Basin, Wyoming and Montana: An Assessment of The Tertiary-Upper Cretaceous Coalbed Methane Total Petroleum System, United States Geological Survey, Denver.

Indobarambai Gas Methane, Procedure of Cleat Measurement.

Koesoemadinata, R.P. dan Matasak, T., 1981, Stratigraphy and Sedimentation Ombilin Basin Central Sumatra (West Sumatra Province), Proceedings of Indonesian Petroleum Association, $10^{\text {th }}$ Annual Convention, 217-249.

Koning, T., 1985, Petroleum Geology of The Ombilin Intermontane Basin, West Sumatra, Proceedings Indonesian Petroleum Association, $14^{\text {th }}$ Annual Convention, 117-137.
Mathew, D., 2007, CBM Workshop: Fundamentals of CBM, Arrow Global CBM.

Moore, C.H., 2001, Carbonate Reservoir: Porosity Evolution and Diagenesis in A Sequence Stratigraphic Framework, Development in Sedimentology Series, Elsevier, Amsterdam.

Nelson, R.A., 2001, Geologic Analysis of Naturally Fractured Reservoirs, Gulf Professional Publishing, Woburn.

Noeradi, D., Djuhaeni, Simanjuntak, B., 2005, Rift Play in Ombilin Basin Outcrop, West Sumatra, Proceedings of Indonesian Petroleum Association, $30^{\text {th }}$ Annual Convention, 39-51.

Olsen, T.N., Brenize, G., Frenzel, T., 2003, Improvement Processes for Coalbed Natural Gas Completion and Stimulation, Society of Petroleum Engineers, SPE Annual Technical Conference and Exhibition, SPE 84122, 1-16.

Pinetown, K., 2009, CBM Exploration Workshop: Coal Petrology and Its Use in Coal Seam Gas Studies, CSIRO Australia.

Prasongko, B.K., Notosiswoyo, S., Anggayana, K., Abdullah, C.I., 2007, Cleat Distribution Controls On The Sulphur Content Of The Miocene Coal Seam In The Palaran And Busui Areas, East Kalimantan, Journal JTM, Vol.XIV No.3, 145-155.

Saghafi, A., 2009, CBM Exploration Workshop: Mechanism of Gas Storage in Coal, CSIRO Australia.

Santoso, B. dan Daulay, B., 2007, Comparative Petrography of Ombilin and Bayah Coals Related to Their Origin, Indonesian Mining Journal, Vol.10 No.9, 1-12.

Silitonga, P.H. dan Kastowo, 1975, Peta Geologi Lembar Solok, Sumatra, Peta Geologi bersistem Sumatera, Pusat Penelitian dan Pengembangan Geologi, Bandung. 
Situmorang, B., Yulihanto, B., Guntur, A., Himawan, R., Jacob, T.G., 1991, Structural Development of The Ombilin Basin West Sumatra, Proceedings Indonesian Petroleum Association, $20^{\text {th }}$ Annual Convention, 2-15.

Stevens, S.H. dan Sani, K., 2001, Coalbed Methane Potential of Indonesia: Preliminary Evaluation of A New Natural Gas Source, Proceedings Indonesian Petroleum Association, $28^{\text {th }}$ Annual Convention, Vol.1, 727738.

Suarez-Ruiz, I. dan Crelling, J.C., 2008, Applied Coal Petrology, Elsevier, Burlington.

Susilawati, S.S.R., 2008, CBM-Gas Metana dalam Batubara, Calon Bahan Bakar Masa Depan, Warta Geologi, Vol.3 No.4, 12-19.

Thomas, L., 2002, Coal Geology, John Wiley \& Sons Itd, Chichester.

Tim Pemboran Dalam Batubara, 2009, Laporan Pemboran Dalam Batubara Di Cekungan Ombilin, Sawahlunto, Provinsi Sumatra Barat, Pusat Sumber Daya Geologi, Bandung.

Ward, C.R., 1984, Coal Geology and Coal Technology, Blackwell Scientific Publications, Melbourne.
Brenda, P., 1993, Coalbed Methane in the Forest City Basin, http://energy.usgs.gov/factsheets/Fo rest/fig1.html, Download (diturunkan/diunduh) pada 10 Maret 2010.

CBM-Coal Bed Methane Gas, http://sites.google.com/site/waterwat challiance/cbm-coal-

bedmethanegas, Download (diturunkan/diunduh) pada 14 Maret 2010.

Coalbed

Methane, http://www.mcdan.com/coalbed_met hane.html, Download (diturunkan/diunduh) pada 14 Maret 2010.

Coal

Information, http://www.uky.edu/KGS/coal/coal_in formation.htm,

Download (diturunkan/diunduh) pada 5 Maret 2010.

Influence of Coal Properties, http://www.coaltech.com.au/Influenc eofCoalProperties.html, Download (diturunkan/diunduh) pada 6 Maret 2010.

What is Coalbed Methane, http://www.layneenergy.com/cbm.ht $\mathrm{ml}$, Download (diturunkan/diunduh) pada 14 Maret 2010.

\begin{tabular}{|ll|}
\hline Diterima & $: 2$ Mei 2017 \\
Direvisi & $: 16$ Mei 2017 \\
Disetujui & $: 31$ Mei 2017
\end{tabular}

